\title{
GaNdHI: A ThOuSAND CONTRADICTIONS - ROUNDTABLE AND ART WORKSHOP. THE EXPERIENCE
}

\author{
SONIYA AMRITLAL PATEL \\ Independent scholar and artist \\ soniyaamritpatel@hotmail.com
}

Received: 01-10-2020

Accepted: 05-11-2020

\begin{abstract}
How does a hands-on creative arts workshop and roundtable session unfold amongst a group of erudite scholars or aspiring academics? This is subtly unveiled in what turned out to be an unforgettable journey, into the person of Mohandas Gandhi and all his eccentricities.
\end{abstract}

KEYWORDS: Gandhi; Ambedkar; History; Art; Workshop; Discussions

RESUMEN GANDHI: Un millar de contradicciones - Mesa redonda y taller artístico. La Experiencia ¿Cómo se desarrolla un taller práctico de artes creativas y una mesa redonda entre un grupo de académicos eruditos o aspirantes a académicos? Esto se desvela sutilmente en lo que resultó ser un viaje inolvidable en la persona de Mohandas Gandhi y todas sus excentricidades.

PALABRAS ClAVE: Gandhi; Ambedkar; historia; arte; taller; intercambio de ideas

What happens when a group of illustrious and delightfully varied individuals come together in a participatory and exploratory creative experience? The occasion was the 6th International Conference organised by the Spanish Association of Interdisciplinary India Studies (AEEII) and the University of Valladolid. It marked 150 years since the birth of Mohandas Karamchand Gandhi and was titled: Gandhi in Contemporary India: Seeking Peace amid Disorders. This particular creative session took place on 27 November 2019, in the premises of the prestigious institute of contemporary art, the Museo Patio Herreriano, located in the scenic university town of Valladolid, in Spain. The experience evolved into an inspiring kaleidoscope of explosive visual and scholarly interchange.

As an artist, the challenge to motivate a group of erudite intellectuals into transferring visions and thoughts, which are habitually eloquently expressed in words, into what was to be a form of visual creative expression was both exhilarating and overwhelming. I was reasonably well accustomed to qualitative outcomes in my creative arts and cultural sessions, but this was no ordinary art workshop. 
Around the table, facing me were the friendly and expectant faces of academic attendees who, in many cases, occupied some of the highest positions in their respective institutions. I was equally thrilled and daunted, while remaining fully aware that the next couple of hours held the promise of an enjoyable, enriching and stimulating exchange for all present.

We commenced our session with conversations around the figure of Gandhi and his multifaceted character, as presented by authors such as Ramachandra Guha, the Guardian columnist, Ian Jack, George Orwell, Judith Brown and Joseph Lelyveld, amongst others. The ensuing discussions were animated and informative, leading to a build-up of emotion, inspiration and energy, which was naturally conducive to achieving the resulting qualitative experience. The session was also accompanied by a slide projection of some of my photographic artwork marking specific periods in Gandhian history, and evocative strains of classical Indian music by well-known names like Pt. Shiv Kumar Sharma, Hariprasad Chaurasia and Ravi Shankar, amongst others.

The practical part of the session commenced in an ambience of excitement and anticipation, accompanied by the mentioned music and possibly, pleasurable childhood memories of dappling with paint and glue. The art pieces that ensued were commendable, irrespective of the fact that many of the participants had perhaps never previously put their hand to creating pictorial art using acrylic paints and collage techniques. The resulting artwork gave rise anew to enthusiastic exchange, as we deliberated over each piece, reflecting on the variety of visual responses and the creative interpretations of both the history of the Gandhian era and the figure of Gandhi himself.

The artwork produced brought up many interrogates, for example, about history's treatment of the figures of Gandhi and B. R. Ambedkar or questions regarding the current condition of subalternity and caste in India. Ambedkar insisted that the caste system was the worst scourge and hindrance to progress in India and it had to be eradicated. The question of whether Gandhi actually did intend this scourge to be addressed remains unresolved. Contradictions that might have borne heavy on Gandhi surfaced and were discussed. Gandhi as a father figure was the father of the nation but had a difficult, arguably dysfunctional relationship with his own sons.

Gandhi's possible but unacknowledged racism, an issue not often touched upon, also emerged within the artistic creations and workshop discussions. As is well-known, Gandhi's activism originated and commenced in South Africa. As a young lawyer, he drew upon examples of black South African 
activists. However, this fact was never clearly acknowledged or credited and Gandhi's discourse was far from inclusive with the black South African struggle or the people themselves. Gandhi is considered to have held a racist position by scholars such as the South Africans, Ashwin Desai and Goolam Vahed. However, others like Ramachandra Guha consider this opinion to be erroneous and over simplistic within the context of the times. Nevertheless, the questions and contradictions remain.

The creative process and discussions during the session led also to what might be understood as a sort of reconciliation with the figure of Gandhi amongst some of the attendees who were critical of his doctrines. This was possible even while maintaining acknowledgment and a general consensus on the radicalism of some of Gandhi's expectations, his stubbornness and his imposition or demands of extreme, often unreasonable, sacrifice amongst those who surrounded him.

The overall workshop experience, added to the generous, unanimous and wholeheartedly positive feedback offered at the end of the session made this a truly unforgettable art and cultural workshop. This was without question an added gift to me, adding manifold to the gratification and pleasure I derive from such opportunities. This particular session evolved into an exceptionally rewarding opportunity. Gratifying is an understatement of what was an opportunity to offer a visual arts and cultural hands-on workshop to the attendees of customarily solely academic forums, as one would find in seminars and conferences. Included are four examples of the artwork produced in this session and a group photograph of attendees. One sincerely looks forward to many more such experiences, which are hopefully as enrichening for all those involved as they are for me.

\section{WORKS CITED}

DESAI, A., \& VAHED, G. (2015). The South African Gandhi: Stretcher-Bearer of Empire. Stanford University Press.

GANDHI, R. (2007). Mohandas: A True Story of a Man, His People, and an Empire. India: Penguin Books.

GUHA, R. (2018). Gandhi 1914-1948: The Years That Changed the World (Kindle/Hardcover/Paperback ed.). UK, Canada, Ireland, Australia, New Zealand, India, South Africa; USA: Penguin Random House UK; Borzoi Book by Alfred Knopf.

LELYVELD, J. (2012). Great Soul: Mahatma Gandhi and His Struggle with India (Paperback ed.). Vintage books, Alfred A. Knopf, a division of Random House. 
SoniYa Amritlal Patel studied at the Faculty of Political \& Social Sciences, (INSTIFEM) in the Complutense University, Madrid, Spain. She obtained a Bachelor of Fine and Applied Arts from the University of Nigeria. A British Indian, she grew up in different parts of Africa. As an artist and researcher, she is fascinated by people and cultures. This interest informs all her artwork and research endeavours. 

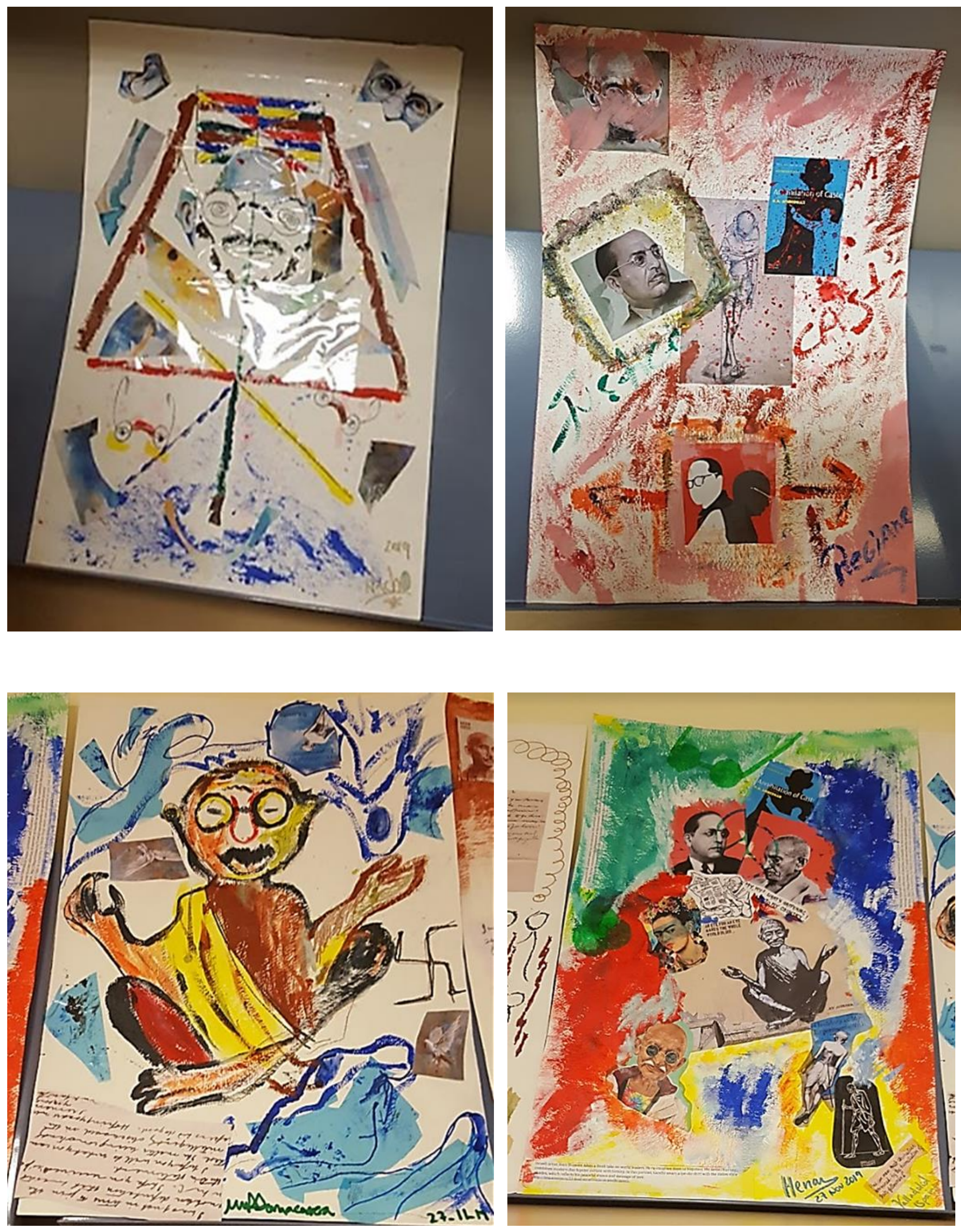


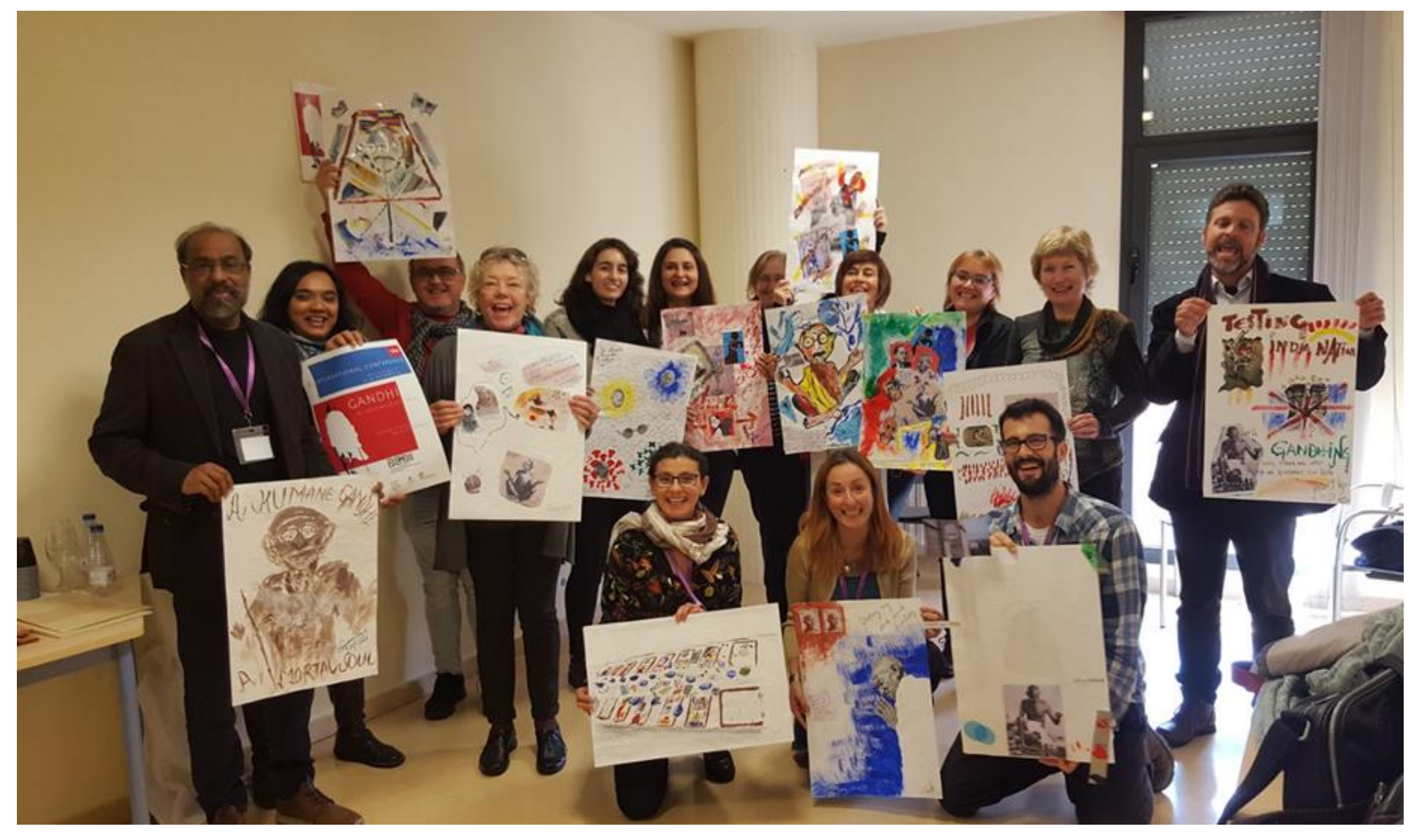

